\title{
PERANAN PROMOSI TERHADAP PENINGKATAN JUMLAH SISWA PADA PRIDE EDUCATION CENTRE (PEC) PEMATANGSIANTAR
}

\author{
Oleh: \\ Sisca Wijaya \\ S1 Manajemen \\ Darwin Lie, Marisi Butarbutar, Efendi
}

\begin{abstract}
Abstraksi
Pride Education Centre (PEC) Pematangsiantar merupakan salah satu usaha yang bergerak dalam bidang jasa pendidikan. Karena masih belum lama resmi menjadi sebuah sekolah TK Plus, maka masih banyak orang yang belum mengetahui atau sedikit orang yang mengenal terhadap keberadaan Pride Education Centre (PEC). Oleh karena itu, Pride Education Centre (PEC) melakukan berbagai cara untuk meningkatkan volume penjualan yang dalam hal ini jumlah konsumen (jumlah siswa) sebanyak-banyaknya. Salah satu usaha yang dilakukan Pride Education Centre (PEC) untuk meningkatkan jumlah siswanya yaitu dengan melakukan promosi. Dalam pelaksanaaan kegiatan promosinya, Pride Education Centre (PEC) Pematangsiantar hanya menggunakan alat promosi yang sesuai dengan kebutuhan dan kondisi sekolah yaitu periklanan, promosi penjualan, dan hubungan masyarakat.

Berdasarkan data biaya promosi yang dilakukan Pride Education Centre (PEC) Pematangsiantar, dapat dilihat bahwa pada tahun 2012 dan 2013, terjadi peningkatan yang signifikan pada biaya promosi yang digunakan Pride Education Centre (PEC) Pematangsiantar yaitu sebesar $105,60 \%$ dan $121,01 \%$. Hal ini disebabkan adanya penambahan media promosi yang digunakan oleh perusahaan yaitu melalui penempatan iklan di surat kabar dan pelaksanaan acara open house. Berdasarkan data jumlah siswa TK Plus Pride Education Centre (PEC) Pematangsiantar, dapat dilihat bahwa pada tahun 2012 dan 2013, realisasi pencapaian target jumlah siswa TK Plus Pride Education Centre (PEC) Pematangsiantar cukup tinggi yakni sebesar $85 \%$ dan 86,73\%. Hal ini membuktikan bahwa promosi yang dilakukan oleh Pride Education Centre (PEC) Pematangsiantar adalah berhasil. Oleh karena itu, dapat dikatakan bahwa kenaikan biaya promosi memiliki peranan terhadap peningkatan volume penjualan yang dalam hal ini jumlah konsumen (jumlah siswa) pada Pride Education Centre (PEC) Pematangsiantar.
\end{abstract}

Kata kunci: Promosi dan Volume Penjualan (Jumlah Siswa)

\section{Abstraction}

Pride Education Centre (PEC) Pematangsiantar is one business that is engaged in educational services. Long as there is still officially became a kindergarten Plus, there is still a lot of people who do not know or a few people who know of the existence of the Pride Education Centre (PEC). Therefore, the Pride Education Centre (PEC) perform a variety of ways to increase sales volume in this case the number of consumers (number of students) as much as possible. One attempt was made Pride Education Centre (PEC) to increase the number of students is to conduct the promotion. In pelaksanaaan promotional activities, Pride Education Centre (PEC) Pematangsiantar only using promotional tools that fit the needs and conditions of schools are advertising, sales promotion, and public relations.

Based on cost data promotion conducted Pride Education Centre ( PEC) Pematangsiantar, it can be seen that in 2012 and 2013, a significant increase in the cost of promotion used Pride Education Centre (PEC) that is equal to 105.60 Pematangsiantar \% and $121.01 \%$. This is due to the addition of a media campaign that used by the company is through the placement of advertisements in newspapers and implementation of the open house. Based on data on the number of students Kindergarten Plus Pride Education Centre ( PEC) Pematangsiantar, it can be seen that in 2012 and 2013, the realization of achieving the target number of students Kindergarten Plus Pride Education Centre ( PEC) Pematangsiantar quite high at $85 \%$ and $86.73 \%$. This proves that the promotion done by the Pride Education Centre (PEC) Pematangsiantar is successful . Therefore, it can be said that the rise in the cost of the campaign has a role to increased sales volume in this case the number of consumers ( number of students) at the Pride Education Centre (PEC) Pematangsiantar.

Keywords : Promotion and Sales Volume (Number of Students)

\section{A. PENDAhuluan}

\section{Latar Belakang Masalah}

Dalam era globalisasi saat ini, persaingan menjadi sangat ketat dan kemampuan untuk eksis dalam persaingan dibutuhkan dalam menentukan suatu keputusan yang tepat pada sasaran. Dengan tingginya tingkat pendidikan masyarakat akan mampu merubah pola pikir, pola sikap dan cara pandang masyarakat agar menjadi lebih sistematis. Oleh karena itu kita harus menyadarkan masyarakat kita mengenai betapa pentingnya pendidikan itu. 
Pride Education Centre (PEC) Pematangsiantar merupakan salah satu usaha yang bergerak dalam bidang jasa pendidikan, yang belum lama resmi menjadi sebuah sekolah TK Plus, sehingga masih banyak orang yang belum mengetahui atau sedikit orang yang mengenal terhadap keberadaan Pride Education Centre (PEC). Oleh karena itu, Pride Education Centre (PEC) melakukan berbagai cara untuk mendapatkan konsumen dalam hal ini siswa sebanyak-banyaknya. Berikut ini adalah data jumlah siswa TK Plus Pride Education Centre (PEC) dari tahun 2009-2013 yaitu: Tabel 1

Jumlah Siswa Tahun 2009-2013

\begin{tabular}{||c|c||}
\hline \hline Tahun & Jumlah Siswa \\
\hline 2009 & 2 \\
\hline 2010 & 13 \\
\hline 2011 & 27 \\
\hline 2012 & 51 \\
\hline 2013 & 85 \\
\hline \hline
\end{tabular}

Sumber : Pride Education Centre (PEC) Pematangsiantar

Dari tabel di atas dapat kita lihat bahwa jumlah siswa TK Plus Pride Education Centre (PEC) mengalami peningkatan dari tahun ke tahun. Salah satu usaha yang dilakukan Pride Education Centre (PEC) untuk meningkatkan jumlah siswanya yaitu dengan melakukan promosi. Kegiatan promosi tersebut dilakukan oleh Pride Education Centre (PEC) agar dapat lebih dikenal oleh masyarakat, terutama orang tua calon siswa sehingga mereka berminat atau tertarik untuk menyekolahkan anaknya di TK Plus tersebut.

Pride Education Centre (PEC) mempromosikan sekolahnya dengan menggunakan jasa iklan yaitu melalui surat kabar dan juga pembagian brosur. Selain itu, Pride Education Centre (PEC) melakukan promosi penjualan dengan cara membebaskan uang pendaftaran kepada siswa baru yang mendaftar pada jangka waktu tertentu yang telah ditentukan. Pride Education Centre (PEC) juga melakukan public relation atau humas dengan cara mengadakan acara open house di sekolah itu sendiri untuk mempresentasikan kepada orang tua calon siswa mengenai jasa pendidikan yang akan diberikan dengan fasilitas yang telah disediakan. Dengan kegiatan promosi yang efektif, Pride Education Centre (PEC) mengharapkan jumlah siswanya dapat terus meningkat dari tahun ke tahun.

\section{Rumusan Masalah}

Berdasarkan latar belakang yang diuraikan sebelumnya, maka penulis mencoba untuk merumuskan masalah dalam penelitian yaitu: bagaimana peranan promosi terhadap peningkatan jumlah siswa pada Pride Education Centre (PEC) Pematangsiantar?

\section{Tujuan Penelitian}

Adapun tujuan dari penelitian ini adalah: untuk mengetahui peranan promosi terhadap peningkatan jumlah siswa pada Pride Education Centre (PEC) Pematangsiantar.

\section{Metode Penelitian}

Desain penelitian merupakan suatu cara yang sistematis dan objektif dengan maksud untuk memperoleh data atau mengumpulkan keterangan untuk diteliti. Adapun Desain penelitian yang digunakan dalam penulisan skripsi ini adalah Penelitian Kepustakaan (Library Research) dan Penelitian Lapangan (Field Research). Sumber data yang digunakan dalam penelitian ini adalah data primer dan data sekunder.

Teknik pengumpulan data yang dilakukan penulis dalam penelitian ini adalah berupa Wawancara dan Dokumentasi. Tehnik analisa data yang digunakan dalam penelitian ini antara lain Tehnik Analisa Deskriptif Kualitatif dan Tehnik Analisa Komparatif.

\section{B. LANDASAN TEORI}

Kegiatan pemasaran sering diartikan sebagai kegiatan penjualan. Sebenarnya pemasaran mempunyai ruang lingkup yang lebih luas, sedangkan penjualan hanyalah merupakan sebagian dari beberapa fungsi pemasaran. Fungsi pemasaran yang sesungguhnya adalah mengidentifikasi kebutuhan konsumen, mengembangkan produk yang tepat, menetapkan harga, melaksanakan distribusi dan promosi yang efektif, sehingga dapat dikatakan bahwa pemasaran itu merupakan rangkaian aktivitas dari proses sosial.

Kotler dan Gary (2008:6) mengungkapkan bahwa pemasaran adalah proses dimana perusahaan menciptakan nilai bagi pelanggan dan membangun hubungan yang kuat dengan pelanggan dengan tujuan untuk menangkap nilai dari pelanggan sebagai imbalannya.

Menurut Boyd, et. al. (2000:18) manajemen pemasaran (marketing management) adalah proses menganalisis, merencanakan, mengkoordinasikan dan mengendalikan program-program yang mencakup pengkonsepan, penetapan harga, promosi, dan distribusi dari produk, jasa, dan gagasan yang dirancang untuk meningkatkan dan memelihara pertukaran yang menguntungkan dengan pasar sasaran untuk mencapai tujuan perusahaan.

Kotler dan Gary (2001:71) mengemukakan ada empat variabel bauran pemasaran yang dikenal dengan 4P product, price, place, promotion, yaitu :

1. Product (Produk) artinya kombinasi barang dan jasa yang ditawarkan oleh perusahaan kepada pasar sasaran.

2. Price (Harga) adalah sejumlah uang yang harus dibayar oleh pelanggan untuk memperoleh produk.

3. Place (Distribusi) meliputi aktivitas perusahaan agar produk mudah didapatkan konsumen sasarannya.

4. Promotion (Promosi) artinya aktivitas mengkomunikasikan keunggulan produk serta membujuk pelanggan sasaran untuk membelinya.

Istilah promosi banyak diartikan sebagai upaya membujuk orang untuk menerima produk, konsep, dan gagasan. Menurut Alma dalam Natalia (2012:13) promosi adalah sejenis komunikasi yang 
memberi penjelasan yang menjelaskan calon konsumen tentang barang dan jasa. Dalam bauran pemasaran jasa unsur promosi mempunyai peranan penting dalam membantu komunikasi positioning jasa kepada konsumen.

Dalam memasarkan produknya, perusahaan memerlukan suatu komunikasi dengan para konsumen, karena dengan adanya komunikasi maka konsumen dapat mengetahui produk yang ditawarkan oleh perusahaan. Menurut Kotler dan Gary (2008:116) bauran promosi (bauran komunikasi pemasaran) adalah paduan spesifik periklanan, promosi penjualan, hubungan mayarakat, penjualan personal, dan sarana pemasaran langsung yang digunakan perusahaan untuk mengomunikasikan nilai pelanggan secara persuasif dan membangun hubungan pelanggan.

Dalam menggunakan alat-alat promosi yang ada, manajer pemasaran harus menetapkan tujuan promosi, memilih pesan dan sarana promosi, menetapkan rencana promosi, dan mengevaluasi hasilnya. Dalam melakukan promosi, setiap unsurunsur promosi yang ada harus diramu secara lembut dengan kegiatan promosi lainnya dalam kerangka upaya tercapainya komunikasi pemasaran terpadu yang menyeluruh.

Tjiptono (2008:226) mengemukakan iklan sebagai bentuk komunikasi tidak langsung yang didasari pada informasi tentang keunggulan atau keuntungan suatu produk, yang disusun sedemikian rupa sehingga menimbulkan rasa menyenangkan yang akan mengubah pikiran seseorang untuk melakukan pembelian.

Menurut Kotler dan Kevin (2008:204) promosi penjualan adalah berbagai jenis insentif jangka pendek untuk mendorong orang mencoba atau membeli produk atau jasa. Dalam melakukan promosi penjualan ini sering menggunakan wiraniaga. Wiraniaga ditugaskan untuk menjelaskan produk perusahaan kepada calon pembeli.

Menurut Tjiptono (2008:230) public relations (hubungan masyarakat) merupakan upaya komunikasi menyeluruh dari suatu perusahaan untuk mempengaruhi persepsi, opini, keyakinan dan sikap berbagai kelompok terhadap perusahaan tersebut. Tujuan hubungan masyarakat yaitu membangun hubungan yang baik dengan berbagai publik perusahaan. Hal ini dicapai dengan memperoleh publisitas yang menguntungkan, membangun "citra korporasi", dan menangani atau mengatasi rumor, cerita, dan kegiatan-kegiatan yang tidak menguntungkan.

Menurut Kotler dan Kevin (2008:204) penjualan pribadi yaitu interaksi tatap muka dengan satu atau beberapa calon pembeli dengan maksud untuk melakukan presentasi, menjawab pertanyaan, dan memperoleh pemesanan.

Menurut Tjiptono (2008:232) direct marketing adalah sistem pemasaran yang bersifat interaktif, yang memanfaatkan satu atau beberapa media iklan untuk menimbulkan respon yang terukur dan atau transaksi di sembarang lokasi. Komunikasi promosi langsung ditujukan kepada konsumen individual, dengan tujuan agar pesan-pesan tersebut ditanggapi konsumen yang bersangkutan, baik melalui telepon, pos atau dengan datang langsung ke tempat pemasar.

Pangaribuan (2013:1) mengemukakan konsumen sebagai setiap orang pemakai barang dan/atau jasa yang tersedia dalam masyarakat, baik bagi kepentingan diri sendiri, keluarga, orang lain, maupun makhluk hidup lain dan tidak untuk diperdagangkan.

Tujuan setiap perusahaan adalah untuk mendapatkan profit yang sebesar-besarnya yang biasanya dapat diperoleh dengan menambah jumlah konsumen dan meningkatkan volume penjualan. Salah satu usaha yang dapat dilakukan perusahaan untuk mencapai hal tersebut yaitu dengan melakukan promosi. Promosi yang dilakukan oleh perusahaan harus tepat untuk memastikan bahwa produk yang tepat dipasarkan pada konsumen yang tepat dengan cara yang tepat.

Promosi berfungsi untuk memengaruhi konsumen dalam kegiatan pembelian atau penggunaan jasa sesuai dengan keinginan dan kebutuhannya. Sehingga dapat dikatakan apabila promosi yang dilakukan perusahaan meningkat yang biasanya dapat dilihat dari besarnya biaya promosi yang dikeluarkan perusahaan maka volume penjualan dan jumlah konsumen juga akan meningkat.

\section{PEMBAHASAN}

\section{Analisa Deskripsi Kualitatif}

Analisis deskriptif kualitatif digunakan untuk memberikan suatu gambaran yang jelas mengenai kegiatan promosi yang dilakukan oleh Pride Education Centre (PEC) Pematangsiantar.

Kegiatan promosi yang dilakukan Pride Education Centre (PEC) Pematangsiantar yaitu:

\section{a. Periklanan (Advertising)}

Periklanan (Advertising) merupakan bentuk komunikasi tidak langsung berupa promosi gagasan, barang, atau jasa yang dilakukan oleh sponsor yang bertujuan untuk menyampaikan informasi, membujuk, mengingatkan serta meyakinkan konsumen untuk melakukan pembelian suatu produk atau jasa. Periklanan dapat digunakan untuk membangun citra jangka panjang bagi suatu produk, dan di sisi lain, mempercepat penjualan. Periklanan dapat secara efisien menjangkau berbagai pembeli yang tersebar secara geografis. Pride Education Centre (PEC) Pematangsiantar menggunakan periklanan dalam menginformasikan produk atau jasa yang ditawarkan. Adapun media periklanan yang digunakan Pride Education Centre (PEC) Pematangsiantar dalam menginformasikan produk atau jasanya yaitu :

1) Spanduk

Sejak tahun 2010, Pride Education Centre (PEC) Pematangsiantar mencetak spanduk yang berisi informasi mengenai alamat sekolah Pride Education Centre (PEC), nomor telepon yang dapat dihubungi serta alamat email sekolah Pride 
Education Centre (PEC) untuk diletakkan di beberapa tempat seperti di depan sekolah Pride Education Centre (PEC), di Jalan Surabaya, Jalan Diponegoro, Jalan Wahidin dan lain sebagainya.

2) Brosur

$$
\text { Pride Education Centre (PEC) }
$$

Pematangsiantar akan membagikan brosur mengenai TK Plusnya pada saat mendekati tahun ajaran baru dengan cara menitipkan brosur tersebut kepada koran Analisa untuk diselipkan di setiap eksemplar dari koran tersebut sehingga setiap orang yang membeli koran Analisa akan mendapatkan brosur tersebut. Dalam brosur tersebut berisi informasi mengenai alamat sekolah Pride Education Centre (PEC), nomor telepon yang dapat dihubungi, alamat email sekolah Pride Education Centre (PEC), program-program yang dijalankan dan metode pembelajaran yang diterapkan oleh guru-guru di Pride Education Centre (PEC) ketika proses pembelajaran berlangsung serta foto-foto selama berlangsungnya kegiatan belajar mengajar.

\section{3) Surat Kabar}

Pada saat mendekati tahun ajaran baru, Pride Education Centre (PEC) Pematangsiantar akan mempromosikan TK Plusnya melalui surat kabar secara berkala sebanyak 4-5 kali melalui koran Posmetro Siantar yang berisi informasi mengenai alamat sekolah Pride Education Centre (PEC), nomor telepon yang dapat dihubungi, alamat email sekolah Pride Education Centre (PEC), programprogram yang akan dijalankan oleh Pride Education Centre (PEC) pada tahun ajaran yang akan datang dan fasilitas-fasilitas yang tersedia di Pride Education Centre (PEC). Periklanan melalui surat kabar dilakukan oleh Pride Education Centre (PEC) sejak tahun 2012.

\section{b. Promosi Penjualan (Sales Promotion)}

Promosi Penjualan (Sales Promotion) adalah berbagai jenis insentif jangka pendek yang dapat diatur untuk merangsang pembelian produk dengan segera dan/atau meningkatkan jumlah barang yang akan dibeli pelanggan. Perusahaan menggunakan alat-alat promosi penjualan itu untuk menciptakan tanggapan yang lebih kuat dan lebih cepat. Promosi penjualan dapat digunakan untuk mendapatkan akibat jangka pendek seperti mendramatisir tawaran produk dan mendorong penjualan yang lentur.

Pride Education Centre (PEC)

Pematangsiantar melaksanakan promosi penjualan dengan cara membebaskan uang pendaftaran kepada siswa baru yang mendaftar pada jangka waktu tertentu yang telah ditentukan untuk menarik lebih banyak pendaftar baru yang ingin mendaftar di Pride Education Centre (PEC).

\section{c. Hubungan Masyarakat (Public Relations)}

Hubungan Masyarakat (Public Relations) adalah upaya komunikasi menyeluruh dari suatu perusahaan yang dirancang untuk mempromosikan atau melindungi citra perusahaan atau masingmasing produknya. Tujuan hubungan masyarakat yaitu untuk membangun hubungan yang baik dengan berbagai publik perusahaan. Kampanye hubungan masyarakat yang dikemas dengan baik dan digunakan bersama dengan elemen bauran promosi lainnya bisa sangat efektif dan ekonomis.

Kegunaan Hubungan Masyarakat (Public Relations) pada Pride Education Centre (PEC) Pematangsiantar adalah untuk memperkenalkan mengenai jasa pendidikan yang akan diberikan dengan fasilitas yang telah disediakan.

kegiatan open house yang diadakan oleh Pride Education Centre (PEC) Pematangsiantar termasuk kepada product publicity, yaitu meliputi upaya untuk mempublikasikan kepada calon konsumen terutama orang tua calon siswa mengenai jasa pendidikan yang ditawarkan dengan fasilitas yang telah disediakan oleh Pride Education Centre (PEC) Pematangsiantar. Selain itu, kegiatan open house tersebut juga termasuk dalam corporate communication, dengan mempromosikan pemahaman tentang Pride Education Centre (PEC) Pematangsiantar sebagai sebuah sekolah TK Plus dan mengenai bangunan sekolah dan ruangan kelas yang tersedia di Pride Education Centre (PEC) Pematangsiantar.

\section{Analisa Deskripsi Komparatif}

\section{a. Analisis Biaya Promosi yang Dilakukan Oleh Pride Education Centre (PEC) Pematangsiantar}

Dalam memilih media promosinya, Pride Education Centre (PEC) Pematangsiantar menetapkan anggaran biaya promosi untuk mengetahui berapa besar biaya yang dibutuhkan untuk mencapai sasaran yang telah ditetapkan yaitu untuk mendapatkan siswa yang sebanyakbanyaknya.

Pada tahun 2010, biaya promosi yang dikeluarkan adalah sebesar Rp 3.570.000,- dengan tingkat persentase sebesar $100 \%$. Pada tahun 2011, terjadi peningkatan biaya promosi sebesar 36,69\% karena jumlah siswa yang mendaftar sebelum jangka waktu yang ditentukan semakin banyak sehingga menyebabkan terjadinya peningkatan biaya promosi penjualan.

Pada tahun 2012 dan 2013, terjadi peningkatan yang signifikan pada biaya promosi yang digunakan Pride Education Centre (PEC) Pematangsiantar yaitu sebesar $105,60 \%$ dan $121,01 \%$. Hal ini terjadi dikarenakan pihak Pride Education Centre (PEC) Pematangsiantar merasa promosi yang dilakukan selama ini masih kurang efektif sehingga diambil kebijakan untuk menambah media promosi yang digunakan melalui penambahan penempatan iklan di surat kabar dan pengadaan acara open house. Pride Education Centre (PEC) Pematangsiantar melakukan kebijakan tersebut untuk mengenalkan TK Plus Pride Education Centre (PEC) kepada masyarakat yang lebih luas lagi. Penurunan promosi dalam bentuk spanduk juga terjadi pada tahun 2012 karena dianggap kurang efektif dalam memperkenalkan TK Plus Pride Education Centre (PEC). 


\section{b. Perkembangan Jumlah Siswa Pride Education Centre (PEC) Pematangsiantar}

Tujuan setiap perusahaan adalah untuk mendapatkan profit yang sebesar-besarnya yang biasanya dapat diperoleh dengan menambah jumlah konsumen dan meningkatkan volume penjualan. Oleh karena itu, Pride Education Centre (PEC) melakukan berbagai cara untuk mendapatkan konsumen dalam hal ini siswa sebanyak-banyaknya.

Dapat dilihat bahwa pada tahun 2011, persentase pencapaian target jumlah siswa cukup rendah sebesar 67,50\%. Hal ini dikarenakan oleh pemakaian media promosi seperti spanduk yang dianggap kurang efektif. Oleh karena itu, pada tahun 2012 pihak Pride Education Centre (PEC) Pematangsiantar mengambil kebijakan untuk menggunakan media promosi yang baru seperti penempatan iklan di surat kabar dan pengadaan acara open house dan mengurangi pemakaian spanduk. Penggunaan media promosi yang baru ini cukup efektif dimana dapat dilihat bahwa pada tahun 2012 dan 2013, realisasi pencapaian target jumlah siswa TK Plus Pride Education Centre (PEC) Pematangsiantar cukup tinggi yaitu sebesar $85 \%$ dan $86,73 \%$. Walaupun belum bisa mencapai target yang diharapkan, namun hasil yang diperoleh cukup memuaskan.

\section{c. Peranan Promosi Terhadap Peningkatan Volume Penjualan (Jumlah Siswa) Pada Pride Education Centre (PEC) Pematangsiantar}

Salah satu usaha yang dilakukan Pride Education Centre (PEC) untuk meningkatkan volume penjualan dan jumlah konsumen dalam hal ini jumlah siswa yaitu dengan melakukan promosi. Kegiatan promosi dilakukan oleh Pride Education Centre (PEC) agar dapat lebih dikenal oleh masyarakat, terutama orang tua calon siswa sehingga mereka berminat atau tertarik untuk menyekolahkan anaknya di TK Plus tersebut.

Seiring dengan kenaikan biaya promosi yang digunakan, jumlah siswa TK Plus Pride Education Centre (PEC) Pematangsiantar juga mengalami peningkatan. Terutama pada tahun 2012 dan 2013, jumlah siswa TK Plus Pride Education Centre (PEC) Pematangsiantar mengalami peningkatan yang signifikan yaitu sebesar 292,31\% dan 553,85\%. Dapat dilihat juga bahwa pada tahun 2012 dan 2013, terjadi peningkatan pada biaya promosi yang digunakan Pride Education Centre (PEC) Pematangsiantar yaitu sebesar $105,60 \%$ dan $121,01 \%$ dikarenakan oleh penggunaan media promosi yang baru seperti penempatan iklan di surat kabar dan pengadaan acara open house.

Dari uraian di atas, dapat disimpulkan bahwa apabila promosi yang dilakukan oleh Pride Education Centre (PEC) Pematangsiantar meningkat yang biasanya dapat dilihat dari besarnya biaya promosi yang dikeluarkan perusahaan maka volume penjualan yang dalam hal ini adalah jumlah konsumen (jumlah siswa) juga akan meningkat. Hal ini membuktikan bahwa promosi yang dilakukan oleh Pride Education Centre (PEC) Pematangsiantar adalah berhasil. Dengan demikian, hipotesis yang menyatakan bahwa kegiatan promosi yang efektif berperan dalam meningkatkan volume penjualan yang dalam hal ini adalah jumlah konsumen (jumlah siswa) pada Pride Education Centre (PEC) Pematangsiantar dapat diterima.

\section{EVALUASI}

\section{a. Periklanan (Advertising)}

Dalam melakukan promosinya, periklanan tidak menjadi prioritas utama bagi pengelola Pride Education Centre (PEC) Pematangsiantar karena hasilnya dianggap kurang efektif dan membutuhkan dana yang besar. Dimana ketiga media periklanan yang digunakan oleh Pride Education Centre (PEC) Pematangsiantar hanya bertujuan sebagai iklan informatif saja dan tidak ada yang bertujuan sebagai iklan persuasif, yang dimaksudkan untuk menciptakan kesukaan, preferensi, keyakinan para orang tua calon siswa untuk menyekolahkan anaknya di TK Plus Pride Education Centre (PEC) Pematangsiantar. Selain itu, Pride Education Centre (PEC) Pematangsiantar hanya mengiklankan Pride Education Centre (PEC) setahun sekali pada saat mendekati tahun ajaran baru dan tidak melakukan pengiklanan secara kontinu.

Oleh karena itu, pada tahun 2012 penggunaan spanduk yang dianggap paling tidak efektif dikurangi penggunaannya dan digantikan dengan penempatan iklan di surat kabar dan pengadaan acara open house. Dalam penggunaan brosur, selain memasukkan foto-foto selama berlangsungnya kegiatan belajar mengajar, Pride Education Centre (PEC) Pematangsiantar juga dapat memasukkan foto-foto yang menunjukkan bangunan dan ruangan kelas TK Plusnya. Dalam penempatan iklan di surat kabar, Pride Education Centre (PEC) Pematangsiantar boleh mempertimbangkan untuk menggunakan surat kabar yang lain seperti koran Analisa ataupun koran SIB yang banyak dibeli oleh masyarakat. Selain itu, Pride Education Centre (PEC) Pematangsiantar juga bisa mempertimbangkan untuk menggunakan media periklanan lain seperti radio, majalah, poster, dan lain sebagainya.

\section{b. Promosi Penjualan (Sales Promotion)}

Promosi penjualan terdiri insentif jangka pendek untuk mendorong pembelanjaan atau penjualan produk atau jasa. Dalam melakukan promosi penjualan, Pride Education Centre (PEC) Pematangsiantar hanya memberikan pembebasan biaya pendaftaran untuk siswa yang mendaftar dalam jangka waktu tertentu yang telah ditentukan.

Dari semua kegiatan promosi yang dilakukan oleh Pride Education Centre (PEC) Pematangsiantar, promosi penjualan menghabiskan biaya promosi terbesar karena jumlah siswa yang mendaftar sebelum jangka waktu yang ditentukan semakin banyak sehingga menyebabkan terjadinya peningkatan biaya promosi penjualan dari tahun ke tahun. Oleh karena itu, Pride Education Centre 
(PEC) Pematangsiantar dapat membatasi kenaikan biaya promosi penjualan yang dikeluarkan dengan menetapkan jumlah siswa yang diberikan gratis biaya pendaftaran seperti hanya kepada 10 orang pendaftar pertama atau hanya memberikan diskon sebesar persen tertentu kepada siswa yang mendaftar dalam jangka waktu tertentu yang telah ditentukan.

\section{c. Hubungan Masyarakat (Public Relations)}

Tujuan Hubungan masyarakat yaitu membangun hubungan yang baik dengan publik perusahaan. Memang idealnya sebuah lembaga terutama yang bergerak dalam bidang pendidikan seperti Pride Education Centre (PEC), lebih efektif dalam mempromosikan lembaganya dengan berhubungan langsung bersama masyarakat, karena masyarakat bisa berinteraksi langsung dengan lembaga sekaligus menilai layak atau tidaknya lembaga tersebut sebagai pilihan mereka.

Dalam melaksanakan promosi hubungan masyarakat, Pride Education Centre (PEC) Pematangsiantar melakukan acara open house untuk mengenalkan sekolahnya kepada orang tua calon siswa dengan cara melakukan presentasi mengenai keadaan sekolah, biaya uang sekolah, programprogram pembelajaran dan prestasi yang sudah dicapai oleh siswa-siswa yang bersekolah di Pride Education Centre (PEC). Karena latar belakang Pride Education Centre (PEC) adalah bergerak pada bidang pendidikan, maka yang dijadikan sebagai program promosi adalah kegiatan yang berkaitan dengan pendidikan karena akan membantu proses peningkatan mutu pendidikan sekolah. Selain itu lebih mudah mempublikasikan Pride Education Centre (PEC) dengan melakukan presentasi di hadapan orang tua calon siswa daripada melalui media promosi yang lain.

Selain mengadakan acara open house, untuk meningkatkan bauran promosi hubungan masyarakat, Pride Education Centre (PEC) juga dapat meningkatkan nama baik (goodwill) sekolah dengan melaksanakan kegiatan-kegiatan yang mengikutsertakan orang tua siswa dan melakukan kegiatan-kegiatan sosial yang dapat meninggalkan kesan masyarakat terhadap sekolah tersebut. Hal tersebut akan membuat semakin banyak orang yang mengenal terhadap keberadaan Pride Education Centre (PEC) Pematangsiantar.

\section{KESIMPULAN DAN SARAN}

\section{Kesimpulan}

Dari hasil analisa peranan promosi terhadap peningkatan jumlah siswa pada Pride Education Centre (PEC) Pematangsiantar diperoleh kesimpulan sebagai berikut :

a. Kebijakan promosi yang dilakukan Pride Education Centre (PEC) Pematangsiantar untuk mengenalkan sekolah TK Plusnya kepada masyarakat luas antara lain melalui penggunaan spanduk, pembagian brosur, promosi penjualan, pemakaian surat kabar, dan pengadaan acara open house.

b. Berdasarkan data biaya promosi yang dilakukan Pride Education Centre (PEC) Pematangsiantar, dapat dilihat bahwa pada tahun 2012 dan 2013, terjadi peningkatan yang signifikan pada biaya promosi yang digunakan Pride Education Centre (PEC) Pematangsiantar yaitu sebesar 105,60\% dan $121,01 \%$. Hal ini terjadi dikarenakan adanya penambahan media promosi yang digunakan oleh perusahaan melalui penempatan iklan di surat kabar dan pelaksanaan acara open house. Pride Education Centre (PEC) Pematangsiantar melakukan kebijakan tersebut untuk mengenalkan TK Plusnya kepada masyarakat yang lebih luas lagi.

c. Berdasarkan data jumlah siswa TK Plus Pride Education Centre (PEC) Pematangsiantar, dapat dilihat bahwa pada tahun 2012 dan 2013, realisasi pencapaian target jumlah siswa TK Plus Pride Education Centre (PEC) Pematangsiantar cukup tinggi yakni sebesar $85 \%$ dan $86,73 \%$. Hal ini membuktikan bahwa promosi yang dilakukan oleh Pride Education Centre (PEC) Pematangsiantar adalah berhasil. Oleh karena itu, dapat dikatakan bahwa kenaikan biaya promosi memiliki peranan terhadap peningkatan jumlah siswa pada Pride Education Centre (PEC) Pematangsiantar.

d. Selain kenaikan biaya promosi, pemilihan media promosi yang tepat juga sangat menentukan keberhasilan kegiatan promosi yang dilakukan untuk mengenalkan sekolah TK Plus Pride Education Centre (PEC) Pematangsiantar kepada masyarakat yang lebih luas lagi.

\section{Saran}

Berdasarkan hasil evaluasi peranan promosi terhadap peningkatan jumlah siswa pada Pride Education Centre (PEC) Pematangsiantar maka penulis menyarankan :

a. Agar pelaksanaan kegiatan promosi Pride Education Centre (PEC) Pematangsiantar dapat ditingkatkan, maka dalam melakukan periklanan selain menggunakan ketiga media periklanan yang sudah ada juga bisa mempertimbangkan untuk menggunakan media periklanan lain seperti radio, majalah, poster, dan lain sebagainya. Dalam pelaksanaan promosi penjualan, Pride Education Centre (PEC) Pematangsiantar dapat mempertimbangkan untuk memberikan diskon sebesar persen tertentu kepada siswa yang mendaftar dalam jangka waktu tertentu yang telah ditentukan daripada memberikan gratis biaya pendaftaran. Dalam hubungan masyarakat, selain mengadakan acara open house, Pride Education Centre (PEC) juga dapat meningkatkan nama baik (goodwill) sekolah dengan melaksanakan kegiatan-kegiatan yang mengikutsertakan orang tua siswa dan 
b. melakukan kegiatan-kegiatan sosial yang dapat meninggalkan kesan masyarakat terhadap sekolah tersebut.

c. Agar dapat mencapai target jumlah siswa yang direncanakan di masa yang akan datang, Pride Education Centre (PEC) Pematangsiantar juga harus lebih agresif untuk merubah atau menambah bentuk kegiatan promosi yang selama ini diterapkan. Perusahaan bisa menggunakan kegiatan promosi lain seperti pemasaran langsung (direct marketing) melalui penggunaan internet agar lebih banyak lagi informasi yang bisa didapat oleh para konsumen.

d. Sehubungan dengan keterbatasan-keterbatasan yang ada pada penulis, dalam penelitian ini masih terdapat kelemahan-kelemahan dan belum dapat mengungkap seluruh variabel yang dapat mempengaruhi peningkatan volume penjualan yang dalam hal ini adalah jumlah konsumen (jumlah siswa) Pride Education Centre (PEC) Pematangsiantar. Sebagai bahan masukan untuk penelitian selanjutnya, perlu memperbanyak variabel penelitian dengan bauran pemasaran yang lain seperti product, price, place, people, physical evidence, dan process.

\section{E. DAFTAR PUSTAKA}

Boyd, et.al, 2000, Manajemen Pemasaran : Suatu Pendekatan Strategis dengan Orientasi Global, Edisi Kedua, Jilid 1, Jakarta : Erlangga.

Kotler, Philip \& Gary Armstrong, 2001, Prinsipprinsip Pemasaran, Edisi Kedelapan, Jilid 1, Jakarta : Erlangga.

Kotler, Philip \& Gary Armstrong, 2008, Prinsipprinsip Pemasaran, Edisi 12, Jilid 1 dan 2, Jakarta : Erlangga.

Kotler, Philip \& Kevin Lane Keller, 2008, Manajemen Pemasaran, Edisi 12, Jilid 2, Jakarta : PT Indeks.

Natalia, 2012, Peranan Promosi dalam Meningkatkan Volume Penjualan Keramik Garuda Pada PT. Garuda Makmur Sentosa Pematangsiantar, Skripsi, STIE Sultan Agung.

Pangaribuan,

Adiman, http://adimanpangaribuan.blogspot.com/20 12/06/ pengertian-konsumen.html: tahun akses 2013.

Tjiptono, Fandy, 2008, Service Management : Mewujudkan Layanan Prima, Edisi 1, Yogyakarta : ANDI.

Tjiptono, Fandy, 2008, Strategi Pemasaran, Edisi Ketiga, Yogyakarta : ANDI. 